\title{
PERAN POLA ASUH BAGI ANAK TERLANTAR DI PANTI SOSIAL ASUHAN ANAK (PSAA) HARAPAN MAJELUK KOTA MATARAM NTB
}

\author{
Abdul Najib, Rosita Wardiana \\ Email:Ainunnajib524@gmail.com
}

\begin{abstract}
Parenting for children is a highly transcendental thing in creating a young generation who has a mandate in social change. Children are the successors who will continue the leadership in the future. The existence of parenting is a behavioral pattern applied to children which is relatively consistent over time and is very influential in the formation of characteristics of children which the impact will be felt by the children either in aspect of positive or negative. Caregivers have a very big responsibility because the success of foster children is very dependent on coaching of caregivers. Therefore, the caregivers can act as a parent in giving the attention, affection and security, brothers in communicating with the children can solve the problems, the teachers in helping to learn, the service in helping to meet the needs of the children. Caregivers are people who play all roles of the orphanage to educate and direct the foster children. The orphanage environment collaborates with community and school teachers where the foster children attend school. Caregivers through foster parents are temporary, where the children must be immediately returned to the care of their parents. In carrying out its role as a caregiver, the social orphan age of children (PSAA) of Harapan Majeluk of Mataram does its job with patience and compassion, because besides acting as a caregiver, caregivers of socialorphanage of children(PSAA) of Harapan Majeluk of Mataram also roles as teachers.
\end{abstract}

Keywords: Roles, Parenting, Waifs. 


\section{A. Pendahuluan}

Anak selaku harapan bangsa dan negara mempunyai kedudukan yang penting dalam kehidupan bermasyarakat, berbangsa, dan bernegara karena anak adalah tunas bangsa yang akan tumbuh dan berkembang menjadi bagian dari generasi. Anak yang berkualitas perlu dipersiapkan sejak dini agar dapat tumbuh dan berkembang secara wajar baik secara rohaniah, jasmaniah maupun sosialnya,sehingga kesejahteraan anak dapat terpenuhi dan apa yang menjadi harapan keluarga, masyarakat,dan bangsa dapat terwujud.

Pertumbuhan dan perkembangan yang wajar bagi anak sangat bermakna. Kenyataan menunjukkan banyak anak yang tidak mampu melaksanakan fungsi dan peranannya serta memenuhi kebutuhan hidupnya dengan baik, diantaranya adalah ketidak mampuan orang tua dalam melaksanakan tugas dan tanggung jawab terhadap pertumbuhan dan perkembangan anak. Untuk bertahan hidup di tengah kehidupan Kota yang keras, anak jalanan biasanya melakukanberbagaipekerjaan disektor informal, baik legal maupun yang ilegal dimata hukum. ${ }^{1}$ Akibatnya anak tidak mempunyai kesempatan untuk tumbuh dan berkembang secara wajar dengan kata lain menjadi terlantar. Pertumbuhan dan perkembangan anak secara wajar tidak dapat terwujud

1 Bagong Suyanto. Masalah Sosial Anak (Jakarta: Prenada Group, 2003), h. 189 tanpa dibarengi kebutuhan-kebutuhan pokok dan pelaksanaan hak-hak anak. Kegagalan dalam proses pemenuhan kebutuhan pokok, akan menyebabkan anak menjadi terlantar baik secara rohani, jasmani maupun sosial sehingga berdampak negatif pada pertumbuhan fisik, perkembangan intelektual, mental, dan sosial anak.

Banyak usaha yang telah dilakukan dalam menangani masalah sosial anak terlantar, baik yang dilakukan pemerintah maupun masyarakat. Dalam menangani masalah kesejahteraan anak terlantar ada duacara, yaitu dengan menggunakan sistem sosial panti dan sistem nonpanti. Selain itu pelayanan sosial dalam bentuk asuhan anak ada tiga jenis, yaitu: adopsi, asuhan keluarga, dan Panti Asuhan. Asuhan dalam panti adalah sebagai pengganti orangtua bagi anak yang terlantar sehingga anak merasa terjamin hidup dalam kelompok anak-anak. Dimana pelayanan yang diberikan berupa penyediaan fasilitas-fasilitas, pemenuhan kebutuhan sandang, pangan, pendidikan, bimbingan rohani serta keterampilan dimana diharapkan anak-anak tersebut dapat mengembangkan pribadi, potensi, kemampuan dan minatnya secara optimal.Sedangkan asuhan non-panti adalah asuhan secara berkelompok dalam rumah bagi anak-anak remaja yang tidak dapat menyesuaikan diri dengan keluarga asuhnya. ${ }^{2}$ Proses

2 Kamaran, Pembinaan Akhlakul Al karimah Anak Yatim Piatu dalam Panti Asuhan 
pelayanan yang dilakukan oleh panti asuhan tersebut sebagai upaya untuk mewujudkan terbinanya dan berkembangnya kehidupan anak terlantar secara wajar. Anak yang disantuni di dalam panti akan mampu berkembang dengan baik apabila pola asuh yang diberikan oleh panti benar-benar sesuai dengan apa yang diharapkan.

Dengan demikian, maka dalam panti asuhan inilah anak yatim, piatu, yatim piatu dan anak terlantar mendapatkan pendidikan, pembinaan dan bimbingan baik yang diberikan oleh instansi terkait, lebih-lebih pembinaan yang langsung diberikan oleh pengasuh pantai, sehingga mengantarkan mereka pada kedewasaan dan kematangan baik jasmani maupun rohani serta memiliki prilaku yang baik. Mendidik dan mengasuh mereka berarti menolong mereka untuk dapat menjadi anggota masyarakat yang baik dan berguna.

Pola asuh merupakan pola prilaku yang diterapkan pada anak yang bersifat relatif konsisten dari waktu ke waktu dan sangat berpengaruh besar dalam pembentukan karakteristik anak yang dampaknya akan dirasakan oleh anak baik dari segi positif atau negatif. ${ }^{3}$ Pengasuh memiliki tanggung jawab yang sangat besar karena keberhasilan anak asuh sangat tergantung pada pembinaan para

Muhammadiyah Mataram(Skripsi, IAIN Mataram, 2002)

3 Sujato Agus, Psikologi Perkembangan (Jakarta: PT Rineka Cipta, 2006), h. 15. pengasuh. Oleh karenanya, pengasuh dapat bertindak sebagai orang tua dalam hal pemberian perhatian kasih sayang dan rasa aman, kakak dalam berkomunikasi dengan anak dan pembantu pemecahan masalah, guru dalam membantu belajar, pelayanan dalam membantu memenuhi keperluan anak.

Dengan melihat luasnya tanggung jawab pengasuh dalam membina dan mendidik anak yatim piatu, maka dalam pembinaan kepribadian muslim bagi anak yatim piatu sangat penting artinya, karena masalah anak yatim piatu merupakan masalah sosial yang dihawatirkan dapat menghambat pembangunan. Prilaku manusia dapat diartikan sebagai ciri-ciri karakteristik yang secara prinsipil dapat dibedakan dengan manusia lainnya. Sedangkan prilaku itu sendiri dapat diartikan sebagai suatu bentuk respon dengan stimulus yang timbul dan manusia merupakan gabungan dari jiwa dan raga yang memiliki sifat-sifat tertentu dan unik. ${ }^{4}$

Mengambilbagiandarihaltersebut, peneliti dalam hal ini terdorong dan tertarik untuk melakukan suatu penelitian dan pengkajian yang lebih mendalam tentang "Peran Pola Asuh BagiAnak Terlantar di Panti Sosial Asuhan Anak(PSAA) Harapan Majeluk Mataram".

Berdasarkan konteks penelitian di atas maka yang menjadi fokus

4 Kartini kartono, Psikologi Perkembangan(Bandung: Mandar Maju, 2007 ), h. 27 
penelitian dalam penelitian ini adalah: (1) Bagaimanakah Peran Pola Asuh dalam Menangani Anak Terlantar di Panti Asuhan Sosial Anak (PSAA) Harapan Majeluk Mataram? Kendala-Kendala yang Dihadapi Dalam Pola Asuh Anak Terlantar di Panti Sosial Asuhan Anak (PSAA) Harapan Majeluk Mataram, dan (3) Upaya dalam Mengatasi Kendala Dalam Pola Asuh Anak Terlantar di Panti Sosial Asuhan Anak (PSAA) Harapan Majeluk Mataram?

\section{B. Kerangka Teoritik}

Peran adalah seperangkat tingkah laku yang diharapkan oleh oranglain terhadap seseorang sesuai kedudukannya dalam satu sistem. Peran dipengaruhi oleh keadaan sosial baik dari dalam maupun dari luar dan bersifat stabil.Peran adalah bentuk dari prilaku yang diharapkan dari seseorang pada situasi sosial tertentu. ${ }^{5}$ Sedangkan pola asuh adalah suatu usaha atau kegiataan yang dilakukan untuk meningkatkan apa yang sudah ada kepada yang lebih baik (sempurna) baik dengan melalui pemeliharaan danbimbingan terhadap apa yang sudah ada. ${ }^{6}$ Pola asuh terhadap anak terdiri dari empat macam yaitu: pola asuh demokratis, otoriter, permisif, dan penelantar. Penerapan pola asuh orang tua sangat penting utamanya adalah seorang ibu karena seorang ibu

5 Sumber http:// www.fadlie.web.id/ search,Pengertian Peran, diambil Tanggal 09 november 2012, pukul 09:14 wita.

6 Ibid, h. 37-38 adalah orang utama bagi anak dan ibu merupakan lingkungan pertama yang dimasuki untuk membina sosialisasi anak. $^{7}$

Pola prilaku merupakan kebiasaankebiasaan yang dilakukan oleh seseorang dengan kencendrungan membentuk suatu pribadi.Dalam melakukan suatu kegiatan yang bertujuan untuk merubah polaprilakuanak. Upayamerubahprilaku anak terbagi dalam 3 (tiga) metode, yaitu: 1). Metode Pendekatan Perorangan (Personal Approach Method) adalah, cara pendekatan dengan cara penyampaian pesan melalui socialization dan extention education terutama pada anak terlantar tentang pentingnya merubah prilaku yang negatif dan positif yang didasarkan atas kesadarannya sendiri, agar masyarakat dapat menerima mereka kembali di tengah-tengah masyarakat. 2). Metode Pendekatan Kelompok (Group Approach Method) adalah, cara penyampaian melalui diskusi yang terfokus pada kelompok serta melibatkan ketua kelompok anak terlantar, anggota anak terlantar,agen perubahan dan pihak yang memilik interest terhadap masalah anak terlantar. Dikomunikasikan tentang kondisi yang terkait dengan prilakuprilaku yang ingin dirubah atau dengan kekurangan yang dimiliki anak. 3). Metode Pendekatan Masal/Umum (Mass Approach Method) adalah, cara penyampaian dengan cara memobilisir lingkungan disekitar anak terlantar, melalui dari keluarga, kelompok, dan lingkungan disekitar anak jalanan.

7 Ibid., h. 16 


\section{Metode Penelitian}

Pendekatan penelitian ini menggunakan metode kualitatif deskriptif, karena permasalahan belum jelas, holistik, kompleks dan dinamis sehingga tidak mungkin data pada situasi sosial tersebut dijaring dengan metode penelitian kuantitatif. Penelitian kualitatif adalah sebagai prosedur yang menghasilkan data deskriptif berupa data lisan dari orang-orang dan pelaku yang dapat diamati. ${ }^{8}$ Dalam penelitian ini sumber data penelitian dipilih secara purposive adalah teknik pengambilan sumber data dengan pertimbangan tertentu. Pertimbangan tertentu, misalnya orang tersebut dianggap lebih tahu tentang apa yang kita harapkan atau mungkin dia sebagai penguasa, sehingga akan memudahkan peneliti menjelajahi obyek/situasi sosial yang akan diteliti.

Tekhnik pengumpulan data yang di gunakan adalah observasi, wawancara, dan dokumentasi. Untuk tekhnik analisis data dilakukan sebelum memasuki lapangan, selama di lapangan dan setelah selesai di lapangan. Analisis selama di lapangan yang digunakan peneliti adalah model Miles and Huberman. Analisis data dilakukan pada saat pengumpulan data berlangsung dan setelah selesai pengumpulan data dalam periode tertentu. Miles and Huberman mengemukakan bahwa aktifitas dalam

8 Lexy J. Moloeng, Metodologi Penelitian Kualitatif, (Bandung:PT Remaja Rosdakarya,2010),h.3." analisis data kualitatif di lakukan secara interaktif dan berlangsung secara terus menerus sampai tuntas sehingga datanya jenuh. ${ }^{9}$ Dalam uji keabsahan data dalam penelitian kualitatif, data dinyatakan valid apabila tidak ada perbedaan antara yang dilaporkan penelitidengan apa yangsesungguhnya terjadi. Adapun yang akan digunakan peneliti dalam menguji keabsahan data yaitu uji kredibilitas, kecakupan refrensi, dan keikutsertaan peneliti.

\section{Paparan Data dan Temuan}

Adapun peranan yang dilakukan Panti Sosial Asuhan Anak (PSAA) Harapan Majeluk Mataram adalah:(1). Panti Sosial Asuhan Anak (PSAA) Harapan Majeluk Mataram berperan sebagai pengajar. Hal ini diungkapkan oleh ibu "FH" bahwa: "Pada saat anak asuh berada di dalam panti asuhan, ketika para pengasuh memberikan pengajaran ketrampilan dan materimateri tentang keagamaan kepada anak asuh". ${ }^{10}$ (2). Panti Sosial Asuhan Anak (PSAA) Harapan Majeluk Mataram berperan sebagai pembimbing "BA" menuturkan bahwa: "Saat anak asuh mendapatkan kesulitan dalam mengerjakan tugas dari sekolah maupun tugas dalam lingkungan panti, membimbing dalam bersikap, tingkah laku, bergaul dan bersosialisasi dengan

9 Sugiyono, Metode Kuantitatif Kualitatif dan R\&D, (Bandung: Alfa Beta. CV, 2 009), h. 246.

10 FH,Wawancara, Panti Sosial Asuhan Anak (PSAA) Harapan Majeluk Mataram, 24 November 2013. 
orang lain. ${ }^{11}$ (3). Panti Sosial Asuhan Anak (PSAA) Harapan Majeluk Mataram berperan sebagai orang tua. "EP" mengatakan: "Saat anak asuh sedang sakit dan membutuhkan perawatan, saat pengasuh merawatnya ketika sedang sakit. Pihak panti asuhan merawatnya dengan kasih sayang seperti anak mereka sendiri. ${ }^{12}$ (4). Panti Sosial Asuhan Anak (PSAA) Harapan Majeluk Mataram berperan sebagai pembantu dan penolong. Diungkapkan juga oleh Pak "MN" bahwa: "Kita membantu ketika anak asuh mendapatkan kesulitan, seperti pada saat anak asuh kesulitan dalam melaksanakan ketrampilan komputer, mengaji dan lain-lain". ${ }^{13}$ (5). Panti Sosial Asuhan Anak (PSAA) Harapan Majeluk Mataram berperan sebagai penengah atau pendamai. Seperti yang diungkapkan oleh "IKM" bahwa: "Mendamaikan anak asuh yang sedang berselisih dengan anak asuh yang lain. Karena di lingkungan panti sering terjadi perselisihan antara anak asuh yang satu dengan yang lain, karena anak asuh masih mempunyai sifat egois yang tinggi. Dalam hal ini pengasuh Panti asuhan berperan sebagai penengah serta pendamai perselisihan anak asuh dan menasehati anak asuh untuk tidak mengulangi, dan ada sanksi

11 BA, Wawancara, Panti Sosial Asuhan Anak (PSAA) Harapan Majeluk Mataram, 24 November 2013.

12 EP, Wawancara, Panti Sosial Asuhan Anak (PSAA) Harapan Majeluk Mataram, 24 November 2013.

13 MN, Wawancara, Panti Sosial Asuhan Anak (PSAA) Harapan Majeluk Mataram, 24 November 2013. jika ada yang mengulangi perbuatan tersebut". ${ }^{14}$

Adanya peranan yang dilakukan Panti Sosial Asuhan Anak (PSAA) Harapan Majeluk Mataram sebagai media orang tua pengganti keluarga dalam pembentukan sikap dan prilaku, dimana anak asuh yang belum terpenuhi kebutuhan sosialnya baik jasmani maupun rohani. Para pengasuh panti selalu memberi bantuan dan pengarahan baik tenaga maupun pikiran dalam setiap tindakan anak asuhnya.

Lembaga Kesejahteraan Sosial Anak memfasilitasi pendidikan/ pelatihan bagi pengasuh dalam hal pengasuhan anak dan perlindungan anak atau selalu mendorong pengasuh untuk selalu meningkatkan kompotensi profesionalnya. Seperti yang di ungkapkan oleh "PM":

"Hubungan pimpinandan pengasuh Panti asuhan dengan ana kasuh dan orang tua anak asuh selama ini mampun menjalin hubungan dengan baik dan saling bekerjasama dalam hal mendidik anak. Dan apabila ada anak yang melanggar akan diberikan sanksi/hukuman". ${ }^{15}$

Secara keseluruhan ditekankan bahwa Panti Asuhan tersebut adalah rumah bagi anak-anak asuh sehingga

14 IKM, Wawancara.Panti Sosial Asuhan Anak (PSAA) Harapan Majeluk Mataram, 25 November 2013

15 MN, Wawancara. Panti Sosial Asuahan Anak (PSAA) Harapan Majeluk Mataram, 23 November 2013 
tercipta hubungan yang baik antara anak asuhan dengan pengasuh dan selalu ditanamkan rasa memiliki, sehingga dalam hal kebersihan Pantia adalah mutlak menjadi tanggungjawab semua penghuni Panti Asuhan. Selain itu para pengasuh juga selalu berusaha memberikan motivasi pada anak-anak asuhnya dalam setiapkegiatan-kegiatan yang ada, sehingga terjalin hubungan yang baik diantara keduanya. Menurut pengasuh yang lain seperti "IKM":

"Metode yang digunakan dalam mengasuh anak-anak asuh di Panti Sosial Asuhan Anak (PSAA) Harapan Majeluk Mataram adalah metode pendekatan kelompok dan metode pendekatan perorangan. Metode kelompok, biasanya digunakan oleh pengasuh dalam proses pertolongan kepada anak asuh, dimana pengasuh menggunakanmediaataupengalaman dalam kelompok untuk membantu anak asuh dalam mencari solusi permasalahan yang dialaminya, agar dapat melaksanakan fungsi sosialnya secara wajar. Dengan metode kelompok ini, permasalahan yang dialami anak asuh bisa diselesaikan secara bersama-sama dan kelompok. Sedangkan metode perorangan biasanya digunakan pengasuh untuk mendengarkan aspirasi atau keluh kesah dari permasalahanpermasalahan yang dihadapi anakanak asuh secara individual" ${ }^{16}$

Umumnya dalam membimbing anak-anak asuh juga dilakukan dengan

16 IKM, Wawancara. Panti Sosial Asuahan Anak (PSAA) Harapan Majeluk Mataram, 23 November 2013 mengadakan pendekatan pada anak asuh, terutama jika anak mempunyai masalah, dan hal ini sangat bergantung pada masalah yang sedang dihadapi oleh anak tersebut. Apabila anak sedang mempunyai masalah biasanya cenderung menjadi anak yang pemurung/ pendiam. Maka langkah kemudian yang dilakukan oleh Panti Asuhan adalah dengan mengadakan pendekatan pada anak asuh yang bersangkutan untuk diketahui keadaan sebenarnya yang sedang terjadi pada anak tersebut dan umumnya anakanak pemalu sehingga para pengasuh yang harus aktif mencari tahu kepada anak asuh tersebut dengan selalu berusaha menanyakan keadaan langsung terhadap anak asuh yang bersangkutan atau bisa juga melalui teman-teman dekatnya dan selanjutnya baru disampaikan pada para pengasuh di Panti.

Sedangkan kendala-kendala yang dihadapi oleh PSAA Harapan Majeluk Mataram dalam peran pola asuh anak terlantar.

1. Masalah Panti Asuhan. Panti asuhan didirikan untuk membina dan mendidik serta memelihara anak-anak agar mendapat kehidupan yang layak baik dari segi ekonomi, sosial, dan pendidikan demi masa depan mereka. Melalui panti asuhan anak didik dengan berbagai disiplin ilmu pengetahuan yang dapat mengembangkan diri anak asuh baik dari segi jasmani dan rohani seperti ilmu 
pengetahuan, kreativitas dan akhlakul karimah. Panti asuhan dapat membentuk pribadi anak menjadi anak yang mandiri dan membentuk sikap diri yang sempurna, panti asuhan memiliki sesuatu yang dapat membuat anak sehingga memperoleh konsep diri yang sempurna sesuai dengan ilmu pengetahuan dan ajaran agama sehingga menjadi anak yang mandiri dan memiliki masa depan yang cerah.Seperti yang diungkapkan oleh “FH”Kepala Panti Sosial asuhan anak (PSAA) Harapan Mataram, sebagaimana dalam kutipan wawancara berikut ini:

Panti Asuhan juga mendorong anak untuk menjalin dan menjaga hubungan dengan teman seusia mereka, baik di dalam panti, sekolah, maupun disekitar lingkungan Panti Sosial Asuhan Anak untuk meningkatkan rasa percaya diri. ${ }^{17}$

2. Masalah Anak Asuh. Setiap anak lahir dalam keadaan tidak sempurna, karena itu melalui pembentukan pribadi, pandangan pribadi serta sikap peribadi di tengah-tengah lingkungan tempat dimana seseorang berada lahir berdasarkan pengetahuan dan pengalaman, sehingga anak memilikipandangan dan keyakinan terhadap dirinya baik yang bersifat positif maupun negatif. Dari

17 FH, wawancara, Panti Sosial Asuhan Anak (PSAA) Harapan Majeluk Mataram, 23 November 2013 hasil wawancara dengan salah satu pengasuh di Panti Sosial Asuhan Anak (PSAA) Harapan Majeluk Mataram yang mengatakan bahwa: a). Kelakuan anak masih tidak sesuai dengan apa yang diinginkan. Menurut salah satu pengasuh yaitu "AH" mengatakan bahwa:

"Sebagian dari anak asuh yang berada di Panti Sosial Asuhan Anak (PSAA) Harapan Majeluk Mataram tersebut kalakuanya masih tidak sesuai dengan yang diinginkan pada saat memberikan pendidikan, atau pada saat sedang menjalankan program Panti, mereka masih sulit diatur dan masih tidak menghiraukan pengasuh" ${ }^{18} \mathrm{Hal}$ ini dikarenakan mereka masih terbawa oleh kelakuan atau tingkah laku semasa mereka masih di lingkungan rumah sebelum mereka masuk di lingkungan panti ini.Kelakuan yang dimaksud seperti mencuri barang temannya, keluyuran malam hari di luar panti, pulang dan pergi tanpa izin dari pengasuh, serta mengganggu temannya. b). Anak masih malas menjalankan program. Seperti yang diungkapkan oleh Ibu MI" bahwa: "Dalam menjalankan program-program panti sebagian masih malas ketika mengikuti program yang sudah ditetapkan, karena anak-anak asuh ini masih juga membawa kelakuan pada saat mereka mash di luar panti, seperti malas bersih-bersih, belajar, sholat berjamaah, dan lainnya". ${ }^{19}$

18 AH, Wawancara. Panti Sosial Asuhan Anak (PSAA) Harapan Majeluk Mataram, 23 November 2013.

19 MI, Wawancara. Panti Sosial Asuhan Anak (PSAA) Harapan Majeluk Mataram, 23 November 2013 
3. Masalah Pengasuh. Dalam hal ini pengasuh adalah orang yang memberikan pengarahan, pendekatan, mendampingi dan menjadi orang tua penggantididalam pantiasuhan. Seperti yang dituturkan oleh "MN"selaku Pengasuh bahwa:

4. Kadang masalah yang dihadapi dalam memberikan pendidikan atau menerapkan program tersebut sang anak juga malas untuk belajar dan menjalankan program-program yang lainnya. ${ }^{20}$

5. Masalah Pengasuhan. Disamping itu, masih banyak faktor yang belum mendukung terlaksanya pengasuhan anak. Menurut "HP", beliau menuturkan:

"Pada saat menerapkan programprogram yang sudah ada di Panti kendala atau masalah yang dihadapi itu menyangkut pada diri sang anak juga, karena sebagian dari anak memiliki karakter atau tempat tinggal yang berbeda-beda dikarenakan mereka masih terbawa oleh kelakuan atau tingkah laku semasa di lingkungan rumah sebelum mereka masuk dilingkungan panti. Kelakuan yang dimaksud seperti mencuri barang temannya, keluyuran malam haridi luar panti, serta mengganggu temannya". ${ }^{21}$

20 MN, Wawancara. Panti Sosial Asuhan Ankak (PSAA) Harapan Majeluk Mataram, 23 November 2013.

21 HP, Wawancara, Panti Sosial Asuhan Anak (PSAA) Harapan Majeluk Mataram, 26 November 2013.
Dari sekian kendala yang dihadapi oleh pengasuh Panti Sosial Asuhan Anak (PSAA) Harapan Majeluk Mataram yang disebutkan diatas. Mereka tidak hanya terbelenggu membiarkan kendala-kendala tersebut selalu terjadi pada saat mengasuh anak asuhnya.Para pengurus panti mempunyai alternatiftersendiri dalam memecahkan atau mengatasi kendalakendala tersebut yang mendukung kelancaran program-program yang ada di Panti.Sebagaimana dikatakan bahwa, dimanapun sebuah lembaga itu selalu terdapat kendala atau masalah-masalah disaat menjalankan suatu program, seperti halnya di atas. Panti Sosial Asuhan Anak (PSAA) Harapan Majeluk Mataram mengalami berbagai macam kendala atau permasalahan di dalam suatu lembaga meski juga terdapat upaya atau cara dalam mengatasinya, karena tidak mungkin suatu lembaga membiarkan permasalahan itu selalu terjadi tanpa mengatasinya, permasalah tersebut bisa membuat tidak tercapainya tujuan dari suatu lembaga.

Lembaga tersebut tidak selalu membiarkan kendala atau permasalahan yang menimpanya selalu terjadi, para pengasuh Panti Sosial Asuhan Anak mempunyai alternatif tersendiri didalam mengatasi kendala tersebut seperti: 1). Masalah Panti Asuhan. Upaya mengatasi kendala atau permasalahan yang dihadapi disaat menghadapi kendala atau masalah yang menyangkut masalah Panti dalam memberikan 
pendidikan terhadap anak-anak yatim, piatu, yatim piatu maupun anak-anak terlantar di dalam panti asuhan ini. Maksud dari pada pendirian Panti Asuhan adalah untuk membantu dan sekaligus sebagai orang tua pengganti bagi anak yang terlantar maupun yang orang tuanya telah meninggal dunia untuk memberikan rasa aman secara lahir batin, memberikan kasih sayang, dan memberikan santunan bagi kehidupan mereka. Tujuannya adalah untuk mengantarkan mereka agar menjadi manusia yang dapat menolong dirinya sendiri,tidak bergantung pada orang lain dan bermanfaat bagi masyarakat. Menurut hasil wawancara peneliti dengan Kepala Panti, bahwa cara mengatasi permasalahan tersebut di antaranya adalah: "Pengurus panti mengajukan proposal ke instansiinstansi yang terkait, agar membantu menangani masalah panti asuhan di mana terdapat kurangannya pasilitas yang mendongkrang pendidikan anak di dalam panti”. ${ }^{22}$ Hal yang sama juga diungkapkan oleh Ibu Patimah selaku Pengasuh bahwa: "Selain sumbangan dari pemerintah sebagian dari masyarakat juga yang berada di wilayah ini mewajibkan dirinya setiap bulan untuk menyumbangkan Zakat, Imfaq, dan Shadaqah-nya, dan ini juga merupakan sebagai dana dalam mengurus anak-anak asuh yang berada di Panti Sosial Asuhan Anak (PSAA) Harapan Majeluk Mataram

22 FH, Wawancara, Panti Sosial Asuhan Anak (PSAA) Harapan Majeluk Mataram, 29 November 2013 tersebut". ${ }^{23}$ 2). Masalah anak asuh. Upaya yang dilakukan dalam menagani masalah anak asuh dalam Panti Sosial Asuhan Anak, yakni anak-anak tidak memiliki pengalaman yang sama. Anak harus diperlakukan sebagai individu berbeda dengan latarbelakang dan pengalaman yang berbeda pula. "AM" beliau mengatakan: "Kesadaran bahwa anak memiliki ikatan emosional dan psikologis dengan keluarga dan komunitas tempat tinggalnya sehingga sang anak belum mampu menjalankan programprogram panti, maka pengasuh selalu memberikan bimbingan terhadap anak yang mempunyai latar belakang tersebut". ${ }^{24} \mathrm{Hal}$ yang sama juga diungkapkan oleh IKM" selaku Pekerja Sosial sekaligus pengasuh bahwa: "Bagi anak-anak asuh yang nakal yang melakukan tindakan kriminal sesama temannya seperti salah satunya mencuri, maka sangsi yang diberikan kepada anak yaitu dikasih peringatan tetapi jika ia mengulanginya, maka ia akan dikelurkan dari Panti secara tidak hormat, tapi jika keputusan tersebut berdasarkan pertimbangan para pengasuh Panti”. ${ }^{25}$ 3). Masalah pengasuh. Yang harus dilakukan dalam menangani permasalah yang dihadapi pengasuh diamana pengasuh harus

23 FA,Wawancara, Panti Sosial Asuhan Anak (PSAA) Harapan Majeluk Mataram, 29 November 2013

$24 \mathrm{MH}$, Wawancara, Panti Sosial Asuhan Anak (PSAA) Harapan Majeluk Mataram, 29 November 2013

25 IKM, Wawancara, Panti Sosial Asuhan Anak (PSAA) Harapan Majeluk Mataram, 29 November 2013 
bertanggung jawab terhadap setiap anak dan melaksanakan tugasnya sebagai pengasuh. Seperti yang dituturkan oleh Ibu Fitriah selaku Kepala Panti bahwa: "Tingkah laku anak asuh yang tidak sesuai dengan keinginan pengasuhnya atau tidak sesuai dengan norma agama, norma masyarakat, dan khususnya tidak sesuai dengan norma yang ada di panti asuhan". ${ }^{26} 4$ ). Masalah Pengasuhan. Adapun cara mengatasi permasalah atau kendala yang dihadapi pengasuh dalam menangani anak terlantar di Panti Sosial Asuhan Anak. Model pengasuhan para pengurus panti ada yang menyenangkan tetapi ada pula yang tidak menyenangkan. Menurut "NN" yang harus diperhatikan dalam pengasuhan anak yakni: "Dalam proses pengasuhan anak, yang harus diperhatikan adalah orang yang mengasuh agar tidak menghambat kedekatan anak dengan pengasuh" ${ }^{27}$

Dengan langkah-langkah tersebut permasalahan dan hambatan yang dihadapi dapat teratasi dan terselesaikan, sehingga apa yang menjadi tujuan Panti Sosial Asuhan Anak (PSAA) Harapan Majeluk Mataram dapat tercapai.

26 FH,Wawancara. Panti Sosial Asuhan Anak(PSAA) Harapan Majeluk Mataram, 24 November 2013.

27 NN, Wawancara. Panti Sosial Asuhan Anak(PSAA) Harapan Majeluk Mataram, 24 November 2013.

\section{E. Analisis Terkait Data dan Temuan}

Suatu permasalahan yang muncul dalam keluarga akan membawa konsekuensi tersendiri bagi perkembangan anak. Ini dapat terjadi ketika orang tua yang berfungsi sebagai pelindung utama dalam keluarga tidak dapat berperan sebagaimana mestinya. Dalam situasi semacam ini jelasakan berpengaruh terhadap kondisi anak secara fisik, emosional maupun intelegensi belum cukup matang, maka dalam hal ini perlu adanya usaha-usaha khusus agar anakanak dari keluarga yang bermasalah tersebut dapat terpenuhi hak-haknya. Salah satu alternatif pemecahan masalah anak-anak dalam keluarga tersebut adalah dengan memasukkan anak ke panti asuhan, dimana panti asuhan adalah menjadi lembaga yang berupaya memberi bantuan bagi anakanak yang mengalami masalah, dengan tujuan agar anak-anak tersebut dapat terpenuhi hak-haknya.

Anak-anak terlantar merupakan masalah nasional yang perlu mendapat perhatian dengan pengasuhan dan pembinaanmentaldanpengetahuannya agar nantinya potensi yang ada dalam dirinya dapat tergali dan termanfaatkan oleh oleh pembangunan bangsa. Pengasuhan dan bimbingan anak terlantar mutlak diperlukan agar terbentuk pribadi-pribadi yang utuh untuk terciptanya kualitas Sumber Daya Manusia seutuhnya. 
Ketika situasi ketelantaran anak dan anak darikeluarga bermasalah dibiarkan tanpa ada usaha penanggulangannya dihawatirkan anakakan frustasi, mereka terhina dan berontak terhadap keadaan. Sebagai Negara yang berkeadilan sosial pemerintah bertanggungjawab terhadap kondidsi anak-anak terlantar. Seperti yang tersebut dalam Pasal 34 Undang-Undang Dasar 1945 yang berbunyi: "fakir miskin dan anak-anak terlantar dipelihara oleh Negara”.

Pada umumnya anak yang datang ke panti asuhan ini karena mengalami kesulitan ekonomi.Selain itu juga sesuai dengan tujuan dari pendirian panti asuhan ini yaitu menampung anak dari keluarga tidak mampu untuk mendapat perawatan, penyantunan, pembinaan, dan pengembangan. Pembinaan dalam kehidupan beragamamerupakan pembinaan dari kepribadian secara keseluruhan karena kehidupan beragama adalah menjadi kebutuhan rohani manusia. Kegiatan pembinaan keagamaan yang dilakukan di Panti Sosial Asuhan Anak (PSAA) Harapan Majeluk Mataram adalah sebagian besar dilakukan oleh anak-anak Panti yang meliputi sholat berjamaah dan meningkatkan pemahaman keagamaan.

Pengasuh adalah orang yang berperan dalam menjalankan segala peranan Panti Asuhan untuk mendidik serta mengarahkan para anak-anak asuhnya. Lingkungan panti adalah dengan cara bekerjasama dengan masyarakat lingkungan sekitar dan dengan guru sekolah tempat anak asuh bersekolah. Pengasuh melalui orang tua asuh bersifat sementara, dimana anak harus segera kembali dalam pengasuhan orang tuanya. Dalam menjalankan perannya sebagai pengasuh, PantiSosial Asuhan Anak (PSAA) Harapan Majeluk Mataram melakukannya dengan penuh kesabaran dan rasa kasih sayang, karena selain berperan sebagai pengasuh, pengasuh Panti Sosial Asuhan Anak (PSAA) Harapan Majeluk Mataram juga berperan sebagai guru.

Panti Sosial Asuhan Anak (PSAA) Harapan Majeluk Mataram pada saat ini mampu menampung anak asuh sebanyak 70 orang anak asuh yang terdiri dari laki-laki dan perempuan. Jumlah anak asuh yang terlantar adalah 23 orang, sedangkan anak yatim berjumlah 18 orang, anak piatu berjumlah 9 orang, dan anak yatim piatu berjumlah 20orang. Anakanak asuh mendapatkan pendidikan seperti di SD berjumlah 8 orang, SMP berjumlah 36 orang, dan SMA berjumlah 26 orang, kontribusi yang diberikan memiliki manfaat yang sangat besar bagi anak terlantar karena dapat merubah kehidupan mereka terutama dari segi prilaku maupun dari segi akhlaknya yang mampu memperbaiki sistem kehidupan dalam keluarganya.

Anak-anak asuh selalu dididik oleh pengasuh tentang budi pekerti, sopan santun, dan tenggang rasa antara sesama penghuni panti dan juga lingkungan sekitar panti. Selanjutnya pendidikan serta peraturan dan 
kehidupan keseharian dalam panti akan terakumulasi dalam diri anak asuh dan ini menjadi pendidikan penting yang selayaknya mereka dapatkan dalam keluarga. Hal ini dapat dilihat bahwa pengasuhan anak asuh dalam Panti Sosial Asuhan Anak (PSAA) Harapan Majeluk Mataram diperlakukan sama di mana tidak membedakan antara anak yatim, piatu, yatim piatu dan anak terlantar.

Panti Sosial Asuhan Anak (PSAA) Harapan Majeluk Mataram adalah sebagai media orang tua pengganti keluarga dalam pembentukan sikapdan perilaku. Anak-anak asuh yang belum terpenuhi segala kebutuhan sosialnya baik jasmani maupun rohani, di Panti Sosial Asuhan Anak (PSAA) Harapan Majeluk Mataram ini semuanya dapat tercukupi dengan baik. Keluarga yang fungsinya tidak terpenuhi dengan baik akan mengakibatkan pertumbuhan jiwa anak terganggu, maka semua peran keluargayang fungsinya tidak terpenuhi dengan baik dapat tergantikan dengan adanya peranan Panti Sosial Asuhan Anak (PSAA) Harapan Majeluk Mataram, sebagai lembaga pengganti keluarga, sehingga anak-anak asuh yang jika nantinya keluar dari Panti Sosial Asuhan Anak (PSAA) Harapan Majeluk Mataram akan dapat menempatkan diri dalam masyarakat dimana dia tinggal dan anak-anak asuh dapat menerapkan kedisiplinan mulai dari diri sendiri dan mungkin akan diterapkan kepada orang lain.
Pendekatan yang dilakukan pengasuh di PSAA Harapan Majeluk Mataram dalam pengasuhan bagi anak asuh, diantara metodemetode tersebut adalah: a). Metode Pendekatan Perorangan. Tekhnik ini dapat dilakukan oleh pengasuh untuk memberikan pengasuhan seperti mendengarkan aspirasi atau keluh kesahdaripermasalahan-permasalahan yang dihadapi anak-anak asuh secara individual. Sehingga diharapkan anakanak asuh akan memberikan respon baik ketika mendapat bimbingan dari pengasuhnya. Dengan tekhnik tersebut hasilnya anak-anak asuh yang mempunyai permasalahan sosial dan individu lebih memiliki sikap terbuka dan merespon dengan baik peraturan, ataupun perintah. b). Metode Pendekatan Kelompok. Salah satu metode pengasuhan untuk memperbaikidanmeningkatkanfungsi sosial individu melalui pengalamanpengalaman kelompok yang disusun secara sadar dan bertujuan. Dapat disimpulakan bahwa, metode kelompok yang biasa digunakan pengasuh dalam proses pertolongan kesejahteraan sosial kepada anak asuh, dimana menggunakan media dan pengalaman dalam kelompok untuk membantu anak asuh dalam menemukan dan mencari solusi permasalahan yang dialaminya, agar dapat melaksanakan fungsi sosialnya secara wajar, contohnya dengan melakukan diskusi kelompok, game, dan out bond. 
Peran yang telah dilakukan oleh PSAA Harapan majeluk adalahsebagai orang tua, pembimbing, dan pengajar anak asuh, agar tidak bosan untuk member nasehat kepada anak dan berusaha untuk menjadi teman/ sahabat yang baik untuk anak sehingga anak akan merasa lebih dekat serta mampu memberikan semangat atau motivasi pada anakanak asuh. Peranan yang dilakukan Panti Sosial Asuhan Anak (PSAA) Harapan Majeluk Mataram ternyata mempunyai pengaruh yang besar dalam meningkatkan pendidikan anak-anak asuhnya, khususnya pengaruh pada anak asuh terlihat dalam cara bersikap terhadap sesama anak asuh, pengasuh, ataupun dengan orang lain. Hal ini dimulai pada anak dengan diberikan latihan-latihan amal yang menyangkut hubungan manusia dengan Tuhan, manusia dengan manusia, dan lingkungannya maka hal ini diinternalisasikan pada kepribadian anak sehingga ajaran agama benarbenar dihayati, dipahami, dan digunakan sebagai pedoman hidup bagi anak asuh. Itu disebabkan karena Panti Sosial Asuhan Anak (PSAA) Harapan Majeluk Mataram banyak berperan dalam hal pembentukan sikap serta tingkah laku yang baik dalam segala hal.

Cara/metode dalam mengasuh pada prinsipnya berlaku sama untuk semua anak. Setiap anak mempunyai hak dan kewajiban sama dalam rangka menuju ke arah kemandirian. Anak dilatih melakukan kedisiplinan dalam hal belajar dan dalam kegiatan seharihari. Dalam Panti Sosial Asuhan Anak (PSAA) Harapan Majeluk Mataram selalu diterapkan peraturan-peraturan yang berlaku bagi semua anakanak asuh, sekalipun ada beberapa peraturan-peraturan tersebut tidak diberikan secara tertulis. Namun bila ada anak- anak asuh yang melanggar ketentuan peraturan PSAA Harapan Majeluk Mataram, maka anak asuh tersebut akan dikenakan sanksi/ hukuman sesuai dengan tingkat kesalahannya. Beberapa peraturan yang diterapkan di Panti Asuhan adalah tentang peraturan untuk melakukan jadwal kegiatan-kegiatan secara tepat waktu, mengharuskan anak asuh untuk meminta ijin sebelum meninggalkan Panti, melarang anak luar panti untuk tidur dalam Panti Asuhan dan sebagainya.

Namun dalam hal sanksi, hukuman yang diberikan oleh pihak panti umumnya hanya untuk membuat anak jera/malu sehingga tidak akan melakukan kesalahan lagi. Tetapi sanksi yang ada di sini seperti push up bagi yang melakukan kesalahan. Hal ini tidak sesuai dengan prinsip pengasuhan yang mengedepankan kasih sayang, bukan sanksi fisik. Pihak Panti harus menganti bentuk sanksi dengan sanksi lain, seperti menghafal pelajaran, ayat-ayat pendek, atau membersihkan halaman. Sanksi semacam ini lebih bisa mendidik dan mengkonstruksikan karakter anak asuh. Dalam mendidik/ mengasuh anak-anak asuh, baik yang sudah besar maupun masih kecil 
seharusnya dilakukan dengan penuh perasaan sehinggaanak-anak asuh tersebut lebih bias mengerti. Hal ini bertujuan untuk lebih dekat dengan anak asuh.

Dalam pengasuhan anak terlantar di panti asuhan terdapat beberapa masalah yang di hadapi. Adapun masalah-masalah yang dihadapi adalah "masalah panti asuhan, anak asuh, pengasuhan, dan masalah pengasuh".

Masalah Panti Asuhan. Masalah yang sering dihadapi dalam panti asuhan adalah kekurangan dana sehingga pasilitas panti masih sangat kekurangan dalam mencetak anakanak asuh yang berada di Panti Sosial Asuhan Anak (PSAA) Harapan Majeluk Mataram menjadi insan yang muttaqin dan kompetetif dalam kereatif,sesuai dengan visi dan misi Panti Asuhan tersebut. Fasilitas yang dimaksud adalah kekurangan komputer, alat-alat tulis, buku-buku yang sesuai dengan kebutuhan pendidikan anak guru komputer. Akibat dari kekurangan tenaga pendidik ini maka sang anak yang dibina dan dibimbing dalam Panti Sosial Asuhan Anak (PSAA) Harapan Majeluk Mataram masih kurang menguasai bahasa inggris serta belum mampu menguasai computer sesuai dengan program panti, karena dengan kekurangan tenaga pendidik serta kekurangan pasilitas pembelajarannya, maka pembelajaran dalam program tersebut jarang dilakukan.

Adapun tujuan didirikannya PSAA Harapan Majeluk Mataram adalah terwujudnya hak atau kebutuhan anak yaitu kelangsungan hidup, tumbuh kembang, perlindungan dan partisipasi. Sesuai dengn tujuan sebagai Lembaga Kesejahteraan Sosial, bahwa panti asuhan tidak hanya bertujuan untuk memberikan pelayanan, pemenuhan kebutuhan fisik semata namun juga berfungsi sebagai tempat kelangsungan hidup dan tumbuh kembang anak-anak terlantar yang diharapkan nantinya mereka dapat hidup secara mandiri dan mampu bersaing dengan anakanak lainnya yang mempunyai orang tua atau berkecukupan.

Masalah-masalah tersebut di atas, senantiasa di hadapi oleh panti asuhan. Oleh karena itu, panti asuhan sebagai pusat pelayanan kesejahteraan anak mempunyai prinsip sebagai pusat pelayanan, pengembangan, perlindungan, penyantunan, dan pencegahan. Masalah Anak Asuh adalah kendala yang dihadapi oleh Panti Sosial Asuhan Anak (PSAA) Harapan Majeluk Mataram dalam melakukan pengasuhan kepada anak asuh diantaranya anak terlantar, anak yatim piatu, dan anak yatim bukan dari segi sarana dan prasarana saja melainkan dari diri sang anak.Faktor yang mempengaruhi prilaku anak asuh adalah sifat bawaan yang sudah ada dalam diri setiap manusia, karena setiap manusia yang dilahirkan kedunia ini baik yang masih primitif, bersahaja, maupun yang sudah modern, sejak Adam dilahirkan sampai ahir zaman. 1). Kelakuan anak yang masih tidak 
sesuai dengan yang diinginkan. Kelakuan yang dimaksud seperti mencuri barang temannya, keluyuran malem hari diluar panti, pulang dan pergi tanpa izin dari pengasuh, serta mengganggu sesama temannya. 2). Anak masih malas melaksanakan program. Dalam menjalankan program panti ada sebagian anak asuh yang masih malas ketika mengikuti perogram yang sudah diterapkan, hal ini dikarenakan sang anak masih juga membawa kelakuan pada saat mereka masih berada diluar panti, seperti ada yangmalas bersih-bersih, belajar, shalat berjamaah, dan lainnya. Masalah Pengasuh. Adalah masalah yang sering dihadapi oleh pengasuh di Panti Sosial Asuhan Anak (PSAA) Harapan Majeluk Mataram adalah pada saat anakanak asuh masih malas menjalankan program yang ada di dalam Panti, karena mengasuh anak bukan hanya merawat atau mengawasi anak asuh saja, melainkan lebih dari itu, yakni meliputi: pendidikan, sopan santun, membentuk latihan-latihan tanggung jawab, pengetahuan, pergaulan, dan sebagainya. Pengasuhan. Anak asuh yang ada di Panti Sosial Asuhan Anak (PSAA) Harapan Majeluk Mataram. Dalam bidang pengasuhan kendala yang sering dihadapi oleh pengasuh adalah dari dirisang anak, karena pada saat menerapkan program-program yang sudah ada di dalam Panti, sebagian anak asuh masih terbawa kelakuan atau tingkah laku semasa berada dilingkungan rumah sebelum masuk kelingkungan panti, seperti mencuri barang temannya, keluyuran di luar Panti, dan mengganggu temannya.

Sistem pelayanan sosial berbasis lembaga seperti Panti Asuhan dipandang sebagai solusi yang paling diandalkan, meski bukan yang terbaik dalam melindungi dan memenuhi kesejahteraan anak, terutama yang termasuk kategori anak yang kurang beruntung seperti anak terlantar. Dalam menjawab berbagai masalah yang telah dipaparkan di atas, dengan demikian ada beberapa langkah yang dilakukan panti asuhan dalam mengatasi kendala yang dihadapi dala pola asuh anak terlantar yaitu:

1. Masalah Panti Asuhan, Di saat mengalami kendala mengenai panti asuhan yakni masih kurangnya alat-alat atau media dalam menjalankan programprogram yang ada dan kurangnya sarana dan prasarana pembelajaran maka dalam mengatasi hal seperti para pengurus panti asuhan membuat proposal untuk diajukan ke berbagai instansi terkait seperti kantor Dinas Sosial dan lembaga sosial lainnya kemudian juga pengurus tidak hanya menyerahkan proposal ke berbagai instansi terkait akan tetapi mereka meminta sumbangan dari masyarakat setempat terutama masyarakat yang mempunyai usaha-usaha yang lebih.

2. Masalah anak asuh, Upaya mengatasi atau menangani permasalahan yang bersumber 
dari anak, di sini para pengasuh PSAA Harapan Majeluk Mataram melakukan pembinaan khusus terhadap anak yang bermasalah. Misalnya anak yang melakukan tindakan kriminal seperti mencuri barang temanya, maka tindakan pengasuh disini dalam memberikan pembinaan terhadap anak yaitu memberikan pembinaan khusus yang menyangkut pemberian pencerahankepada mereka tentang tindakan yang mereka lakukan. kemudian memberikan suatu hukuman terhadap anak tersebut. Memberikan hukuman kepada mereka sesuai dengan kesalahan yang mereka perbuatan, tanpa harus menggunakan kekerasan atau hal semacam yang membuat mereka merasa tidak tertekan.

Walaupun hukuman itu diperbolehkan sebagai metode dalam mendidik di dalam Islam, tetapi kita tidak boleh lupa bahwa yang utama ketika berinteraksi dengan anak-anak adalah penuh dengan kasih sayang dan lemah lembut.

3. Masalah pengasuh, Upaya yang dilakukan pengasuh dalam menangani anak terlantar di Panti Sosial Asuhan Anak (PSAA) Harapan Majeluk Mataram dengan mengupayakan kedekatan dengan anak agar mereka dapat bercerita secaraterbuka tentang masalah yang mereka hadapi. Dan pengasuh juga mendukung anak dalam mengambil keputusan yang terkait dengan pendidikannya, melalui diskusi dengan teman, juga dengan orang tua dan pengasuh yang ikut memberi pertimbangan. Yang perlu diperhatikan juga oleh penguruspantiyaitumenambahdan meningkatkan kualitas pengasuh dengan mengikuti pelatihanpelatihan agar pengasuhan yang diberikan kepada anak sesuai dengan apa yang menjadi visi dan misi dari Panti itu sendiri.

4. Masalah pengasuhan, Cara mengatasi permasalahan dalam mengasuh anak terlantar di PSAA Harapan Majeluk Mataram seperti melakukan pendekatan kepada anak asuh dengan penuh kesabaran serta memberkan motivasi atau dorongan mental spiritual kepada anak yang memiliki masalah dan membantu mencari solusi dari permasalahan yang sedang dialami oleh anak asuh. Memeberikan pengawasan yang ekstra kepada anak asuh terutama kepada anak yang sedang ada masalah. Memberikan nasehat serta masukan sesuai dengan usia dan karakter serta masalah yang dihadapi anak. Dalam mengasuh anak terlantar, yatim, dan piatu pada prinsipnya bukan hanya terbatas pada lembaga atau sebuah organisasi, namun merupakan tugas dan tanggung jawab semua pengasuh.

Dengan langkah-langkah tersebut permasalahan dan hambatan 
yang dihadapi dapat teratasi dan terselesaikan dan dapat diantisipasi dengan cara berpartisipasi atau kerja sama yang baik antara pemerintah umumnya dan instansi terkait khususnya, masyarakat dan pengelola panti asuhan atau semua pihak kiranya dapat melibatkan diri serta memiliki rasa kepedulian untuk membimbing, membina, mendidik dan mengasuh anak-anakpantidengan mengharapkan ridho dari Allah SWT.

\section{F. Kesimpulan}

Berdasarkan hasil penelitian pada peran pola asuh bagi anak terlantar di PSAA Harapan Majeluk Mataram peneliti dapat disimpulkan sebagai berikut:peranan yang dilakukan Panti Sosial Asuh Anak (PSAA) Harapan Majeluk Mataram tersebut adalah pengganti keluarga atau orang tua, penyangga rasa takut, pembawa kasih sayang dan perhatian. Sedangkan Kendala-kendala yang dihadapi dalam pengasuhan anak terlantar di Panti Sosial Asuhan Anak (PSAA) Harapan Majeluk Mataram adalah, Pertama, keterbatasan sarana dan prasarana. Kedua, anak asuh masih malas menjalankan program yang ada. Ketiga, masalah pengasuh adalah pengasuh yang sering mengeluh menghadapi anak panti. Adapun upaya yang dilakukan oleh Panti Sosial Asuhan Anak (PSAA) Harapan Majeluk Mataram dalam mengatasi kendala-kendala dalam pola asuh anak terlantar adalah: a). Pendekatan kepada anak asuh, b). perbaikan sarana dan prasarana, c). Memberikan pengawasan dan motivasi yang ekstra.

Dalam menggapai proses pendidikan terhadap anak yang merupakan tonggak estapet dan generasi penerus maka ada beberapa hal yang penulis rekomendasikan diantaranya: 1). Pengasuh harus memahami psikologis anak. 2). Gunakan pendekatan yang bernbasis strength perspective dalam memandang anak. 3). Kesalahan-kesalahan yang dihadapi oleh anak jangan dipandang sebagai sebuah penyimpangan, namun lihatlah motif dibalik perbuatan anak karena anak sesungguhnya adalah korban dari lingkungannya. 4). Person in environmental (PIE) merupakan model intervensi terhadap anak dengan segala kerabat dan kolegannya.

\section{Daftar Pustaka}

Arikunto, Suharsimi, ProsedurPenelitian Suatu Pendekatan Praktik. Jakarta: Rineka Cipta Edisi VI cet-13, 2006.

, Metode Penelitian Kuantitatif Kualitatif dan R\&D. Bandung: Alfabeta, 2011.

Bagong suyanto.Masalah Sosial Anak. Jakarta: Prenada Group, 2003.

Cholid Narbuko, Metodologi Penelitian. Jakarta: Bumi Aksara, 2004.

Depag RI."Al-Qur'an dan Terjemahan". Jakarta:1990.

DEPDIKBUD, Kamus Besar Bahas Indonesia. Edisi ke-II. Jakarta: Balai Pustaka, 1997. 
Departenen pendidikan dan Nur hasanah, Pola Pembinaan kebudayaan,Kamus Besar Bahasa Anak Asuh di Panti Asuhan AlIndonesia, Jakarta: Balai Pustaka

Http://batlc of-speech.blogspot. com/2010/10/perspektif- anakjalanan dane-fektivitas.hyml

Http: / / id.shvoong./ social-sciences / education/2261303-pengertianpola-intraksi/ \#ixzz29EgMLb6K. com

Kartini Kartono, Psikologi Perkembangan. Bandung: Mandar Maju, 2007.

Mar'atun Naziah. Pola Pembinaan Anak Asuh Dalam Persfektif Pendidikan Islam di Panti Asuhan Al-ishlahDasan Agung Tanak Beak Batukliang Lombok Tengah, (Skripsi IAIN Mataram, 1988)..

Moleong, Lexi J. Metodologi Penelitian Kualitatif. Jakarta: Ghalia Indonesia, 1994.

Muh. Save Dagun. Psikologi Keluarga. Jakarta: Rineka Cipta, 2012 Husaini Sanggeng Kelebuh Praya LombokTengah dalam persfektif Pendidikan Islam, (Skripsi IAIN Mataram, 2002 / 2003).

Pourwadarminta, Kamus Psikologi. Jakarta: rineka cipta, 1976.

RiyantoYatim. Metodologi Penelitian Pendidikan.Surabaya: Cetakan ke-II SIC, 2001

Sarlito, Wirawan Sarwono, Psikologi Remaja. Jakarta: Rajawali Pers, 1977.

Sugiyono, Memahami Penelitian Kualitatif. Bandung: Alfabeta, 2005.

Sujato Agus, PsikologiPerkembangan. Jakarta: PT Rineka Cipta, 1996.

Save The Children dan Kemensos. Standar Nasional Pengasuhan untuk Lembaga Kesejahteraan Sosial Anak. Jakarta: Balai Pustaka, 2006. 